\title{
Improving the hygiene of jamu sellers in Malang through the provision of appropriate technology
}

\author{
N. Nurwidodo ${ }^{a, 1}$, M. Mulyono b,2, Ahmad Fauzi ${ }^{a, 3, *}$ \\ ${ }^{a}$ Department of Biology Education, Faculty of Teacher Training and Education, Universitas Muhammadiyah Malang, Jl. Raya Tlogomas No. 246, \\ Malang, East Java 65144, Indonesia \\ ${ }^{b}$ Department of Mechanical Engineering, Faculty of Engineering, Universitas Muhammadiyah Malang, Jl. Raya Tlogomas No. 246, Malang, East Java \\ 65144, Indonesia \\ nurwidodo@umm.ac.id;2mulyono@umm.ac.id;3ahmad_fauzi@umm.ac.id* \\ * Corresponding author
}

\begin{tabular}{|c|c|}
\hline ARTICLE INFO & ABSTRACT \\
\hline $\begin{array}{l}\text { Article history } \\
\text { Received: 2021-05-13 } \\
\text { Revised: 2021-08-20 } \\
\text { Accepted: 2021-08-24 } \\
\text { Published: 2021-08-24 } \\
\text { Keywords } \\
\text { Appropriate technology } \\
\text { Herbal medicine } \\
\text { Hygiene } \\
\text { Jamu }\end{array}$ & $\begin{array}{l}\text { Jamu (herbal medicine) is included in traditional health drinks that its processing is often less } \\
\text { hygienic. The purpose of this community service program is to improve the cleanliness of the herbal } \\
\text { medicine-making process in the herbal medicine group in Malang through the provision of hygienic } \\
\text { herbal medicine processing machines. Community service activities were carried out in } 2018 \text { by } \\
\text { involving herbal medicine groups in Tegalgondo and Jetis Villages, Malang. The community service } \\
\text { activities included analyzing the conditions and needs of partners, designing herbal medicine } \\
\text { machines as needed, as well as assisting the use of machines. The implementation methods in this } \\
\text { service program were discussion and training. The result of this service activity was an increase in } \\
\text { partner knowledge regarding the importance of hygiene and the use of appropriate technology in } \\
\text { herbal medicine processing. After the training was carried out, service partners began to be moved } \\
\text { to process jamu more hygienically. Furthermore, assistance and technology-based marketing } \\
\text { training activities also need to be carried out. }\end{array}$ \\
\hline
\end{tabular}

\begin{tabular}{ll}
\hline Kata kunci & Meningkatkan higienitas penjual jamu di Malang melalui penyediaan teknologi tepat guna. Jamu \\
Higienitas & termasuk dalam minuman kesehatan tradisional yang pemrosesannya sering kali kurang higienis. \\
Jamu & Tujuan program pengabdian ini adalah untuk meningkatkan kebersihan proses pembuatan jamu \\
Obat herbal & kelompok jamu di Malang melalui penyediaan mesih pengolahan jamu yang higienis. Kegiatan \\
pengabdian dilakukan pada tahun 2018 dengan melibatkan kelompok jamu di Desa Tegalgondo dan \\
Teknologi tepat guna \\
Jetis, Malang. Kegiatan pengabdian meliputi analisis kondisi dan kebutuhan mitra, pendesainan \\
mesin jamu sesuai kebutuhan, hingga pendampingan penggunaan mesin. Metode pelaksanaan \\
dalam program pengabdian ini meliputi diskusi dan pelatihan. Hasil dari kegiatan pengabdian ini \\
adalah peningkatan pengetahuan mitra terkait pentingnya higienitas serta penggunaan teknologi \\
tepat guna dalam pengolahan jamu. Setelah pelatihan dilakukan, mitra pengabdian mulai tergerak \\
untuk memproses pembuatan jamu dengan lebih higienis. Lebih lanjut, pendampingan secara \\
berkelanjutan perlu dilakukan dan kegiatan pelatihan pemasaran berbasis teknologi juga perlu \\
dilaksanakan.
\end{tabular}

Copyright (C) 2021, Nurwidodo et al. This is an open access article under the CC-BY-SA license

Check for updates

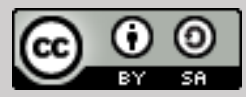

How to cite: Nurwidodo, N., Mulyono, M., \& Fauzi, A. (2021). Improving the hygiene of jamu sellers in Malang through the provision of appropriate technology. Journal of Community Service and Empowerment, 2(3), 95-102. https://doi.org/10.22219/jcse.v2i3.16541

\section{INTRODUCTION}

Jamu consumption is a one of the Indonesian cultures that is easily found today. The tradition of consuming herbal medicine by the Indonesian has been carried out for ages (Elfahmi et al., 2014; I. Wijaya, 2012). This traditional drink is often consumed as it is believed to cure various health problems as well as to maintain the shape of woman's body (Natadjaja et al., 2014). The beginning of consuming this herbal medicine in the tradition of Indonesian society is not well 
known. However, this culture is predicted to have been practiced by the society of ancient Java for more than 10 centuries ago (Yulagustinus \& Tridjaja, 2017).

Along with the high public interest in herbal medicine, in Indonesia, jamu can be produced by anyone from national scale companies to home scale traditional sellers (Gunawan \& Mustofa, 2017). Furthermore, Indonesia is known to have around 17 herbal medicine companies (Elfahmi et al., 2014). The government continuously supports the development of herbal medicine marketing and research in Indonesia (Yulagustinus \& Tridjaja, 2017). In line with this notion, research activities, publication, to the provision of database related to herbal medicine also continue to develop in Indonesia (S. $\mathrm{H}$. Wijaya et al., 2016). The development of marketing and research related to herbal medicine has a positive impact on the culture of Indonesian society. Unfortunately, this condition also has a negative impact on traditional herbal medicine entrepreneurs around the community.

The risk faced by traditional herbal medicine entrepreneurs amid the development of marketing and research related to herbal medicine are the issues around product quality and market competition. The decline in market share will affect in low income or even kill the business of the traditional herbal medicine sellers. The main factor contributing to low product quality and the loss of competitiveness of traditional herbal medicine sellers is the low hygiene in production process (Torri, 2013). Hygiene is an issue that continuously raised related to the quality of herbal medicine (Elfahmi et al., 2014; Torri, 2013). Although herbal medicine is believed to be healthy for the body, unhygienic products can lead to serious health problems for the consumers. Unhygienic process of herbal medicine production have also been reported to cause the herbal medicine to get contaminated with various harmful microbes (Fhitryani et al., 2017; Primatika et al., 2015; Sukmawati et al., 2012). The microbes, apart from causing health problems, will also cause to low product storability (Mills et al., 2014; Valero et al., 2012).

Other than hygiene issue, production capability is another factor that causes traditional herbal medicine sellers to be unable to compete with modern herbal medicine manufacture. Production ability is related to the supply of raw materials, labor in manufacturing process, as well as manufacturing tools or production machine. The low production capability of traditional herbal medicine sellers is an issue that must be taken into account as Indonesia is known to have around 17 national-scale herbal medicine companies with very high production capability (Elfahmi et al., 2014). If it is not addressed, many traditional herbal medicines will lose their livelihoods.

Several community services programs have been carried out by several team aiming at overcoming problems experienced by the traditional herbal medicine sellers in Indonesia. Several programs had been conducted focusing to improve production skills (Lailiyah et al., 2020; Suci Asriani et al., 2015; Widyowati et al., 2018) and improving production (Basri \& Assidiq, 2019; Rahardjanto et al., 2019; Zuhrie et al., 2018). Other community service programs focus on educating packaging methods (Maulan \& Fikriah, 2020) and expanding herbal medicine marketing (Wadjdi et al., 2020). Among the various community service activities, it is analyzed that appropriate technology-based program has not been done yet that aims to rise the hygiene problem in the herbal medicine production process. Whereas, the problems on low hygiene and production capability can be solved if the sellers are able to use production machine in producing the herbal medicine. Therefore, this community service aims to overcome problems on hygiene and low production capability of traditional herbal medicine sellers in Malang, Indonesia. This community service activity is in line with the third goal of Sustainable Development Goals (SDGs), it is to create good health in community and to improve their welfare. By maintaining the quality of traditional herbal medicine, the health of community who consume the traditional herbal medicine will be well maintained. In addition, with the improvement of quality and quantity of traditional herbal medicine production, the welfare of traditional herbal medicine sellers will also get improved.

\section{METHOD}

The community service activity reported in this article focuses on designing and distributing appropriate technology that is able to overcome the problems of traditional herbal medicine sellers in the area around Universitas Muhammadiyah Malang. This community service was done during 2018. The community service partners were two groups of herbal medicine sellers in Malang, Indonesia. The two groups of herbal medicine seller who became the partners both were small-scale traders. The partner produced herbal medicine on small scale with a narrow marketing reach, thus, they had a limited marketing scope. The product selling was only done by peddling around the home area.

The first partner was a community group whose members produced traditional herbal medicine that marketing was sold around their home area with the help of motorbikes. The activity and production center of this group was located at Jetis, Malang. The head of the community group is named Sumani. According to the result of observations and interviews, the herbal medicine production process was still done manually and the amount of production was low. The production capacity was only 20 bottles of mineral water that equals to 1.5 liter per day.

The second partner head office was located in Tegalgondo Village Malang. The second partner was traditional herbal medicine sellers whose sales were around, from one house to another. The herbal medicine sellers did not use any means of transportation, so the sale was done on foot by carrying the herbal medicine on the body. The head of this second partner named Siyatin. Its marketing area was only limited to Dadaprejo Village, Areng-areng, Malang. Similar to the first partner, the second partner still used the manual method in producing the herbal medicine. The production of Siyatin 
herbal medicine were 15 bottles of mineral water that equals to 1,5 liters per day. The herbal medicine produced and sold by Siyatin were herbs made of saffron-colored rice, turmeric, keja, betel, and huyup uyup.

There were two service methods implemented in this program, they were discussion and training. In more detail, the activities involved: (1) identifying the problems faced by traditional herbal medicine sellers through observation and interviews; (2) analyzing alternative solutions to solve the problems of herbal medicine sellers utilizing appropriate technology; (3) designing appropriate technology; (4) preparing and procuring the appropriate technology that includes grinding machines, packaging machines, and information and communication technology for marketing; (5) training on the use of technology by selected traditional herbal medicine sales partners; and (6) monitoring and evaluating the use of technology that has been developed and implemented on aspects of improving the quality and quantity of herbal products as well as aspects of income obtained by herbal medicine sales partners.

There were two machines developed in this community service activity, they were a grinding machine and a packaging machine. The herbal raw material grinding machine is a machine developed to process the basic ingredients to produce traditional herbal medicine into herbal powder with a fine texture. This machine can refine herbal raw materials into fine powders in a faster time than the manual production process. The machine is designed to have a production rate of 25 $\mathrm{kg} / \mathrm{day}$. The basic material of the machine is stainless steel. The operation of the machine uses the help of electricity and an LPG stove. The main component of the machine is the grinder that composed of a rotor that rotates due to the electrical power that enters the machine. In addition, the herbal medicine packaging of herbal products was developed to help packing the products to be more presentable and modern. There were two herbal packaging machines, herbal powder packaging and herbal drink (liquid) packaging. The machine for powder adapted from pedal sealer machine that is operated using electric power and leg pull. On the other hand, the herbal drink was adapted from cup sealer machine. This machine was developed with the purpose of covering the glass lid using plastic material.

The grinding machine and packaging machine were designed into a single equipment system that allowed herbal medicine sellers to carry out the production process from the earliest stages to packaging. In the production process, equipment system, there were several components that made up the production system, they were grinder, manual press, cooking vessel, dispenser, evaporator, and packaging equipment. This production system was produced at the Machine Workshop of Karya Brawijaya located at Jl. Sidomakmur 76 A, Mulyoagung, Dau, Malang.

After both machines were produced, the machines were distributed to partners. Each partner received one unit of herbal medicine. Then, training on the use of herbal medicine production equipment was carried out by involving resource person from the service team and the workshop that had developed the machine. The training was also assisted by several students from Universitas Muhammadiyah Malang who played as training companions, assisting in communication between partners and team leaders, as well as distributing tools and materials needed by partners during the service program.

Observation and interviews were chosen as data collection techniques in this community service activity. Observation was focused on the traditional herbal medicine production process carried out by the two groups of herbal medicine sellers, meanwhile, the interviews were focused on revealing the condition of the sale of herbs of partners. The research data collected were then analyzed descriptively. The community service activities are considered successful if partners are able to use the technology provided and trained by the project team.

\section{RESULTS AND DISCUSSION}

This community service activity begins with a preparatory meeting discussing the steps and activities will be carried out next. The project team then held a meeting to coordinate and conduct internal consolidation to synchronize perceptions among the project team as well as to plan activities to be done next. In addition to involving the team, this initial preparation and coordination also involved students appointed to assist in community service activities. The project team also discussed about providing help and mentoring to partners. During the session, the project team stated to provide business capital for ingredients of herbal medicine production, as well as providing appropriate technology assistance as a solution to improve the quality of partner herbal medicine production.

In addition to carrying out the internal coordination, the team then communicated with partner companies and partner communities. The partner company was Machine Workshop of Karya Brawijaya whereas the partners were the two groups of herbal medicine sellers. The communication with the company resulted in a decision that the machine that had been previously communicated should be immediately put into production. The machine were the two kinds of machines, both were machines to produce drink (liquid) herbs and dry (powder) herbs. The communication with partners was done aiming at informing them that the program previously conveyed will be carried out in the near future. In this initial communication, it was also conveyed to the partner group that training will be held on the use of technology that will be provided to them. Socialization in regards of the cleanliness of the production process was conveyed in the initial communication.

Before this community service activity was undertaken, the process of herbal medicine production carried out by the partners was still far from hygiene. The two groups of community selected as the research subject still used simple kitchen utensils. The simple kitchen was the kitchen of their own. In the kitchen, herbal ingredients were processed into herbal 
drinks which were then put into herbal drinks then poured into mineral water bottles. Figure 1 presents several photos that represent the condition of the herbal medicine-making equipment and the kitchens of the two herbal medicine sellers.

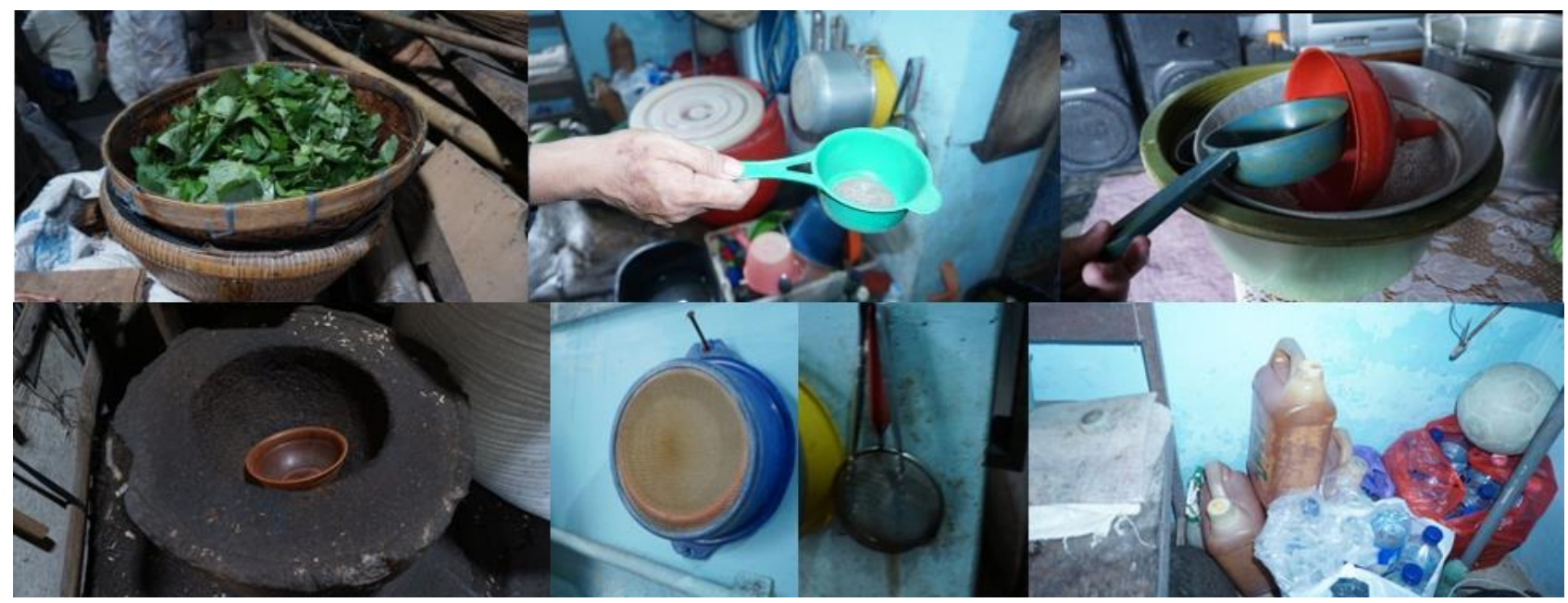

Figure 1. The condition of partners' kitchen utensils used for herbal medicine production

Based on Figure 1, it can be seen that the equipment used by the two herbal medicine traders is still simple and manual. In addition, some kitchen utensils and conditions tend to reduce the level of cleanliness/hygiene of herbs being produced. Unhygienic products can cause the herbal products to be contaminated by various microbes. This condition causes the herbs produced by Sumani and Siyatin to last only one day. In addition, the production of the herbal medicine process in general is through grinding and heating using and LPG stove. The heating can cause nutrition of the herbal ingredients damaged.

Hygiene is one of the research focuses that mostly chosen by traditional herbal medicine researchers (Fhitryani et al., 2017; Primatika et al., 2015; Sukmawati et al., 2012). Several studies report that traditional herbal medicine produced by traditional herbal medicine sellers is potential to get contaminated by various microbes. The contamination can occur during the production process, packaging, sales process, to the time of consumption by consumers. Cleanliness of equipment plays an important role in these conditions.

Unsterilized production process and traditional herbal medicine packaging can cause another problem. The problem is the short shelf life of the herbal medicine. The shelf life of the product only lasts for one day because of the various microbial contaminants in the herbal medicine. As a result, after one day of production, the drink is no longer good to be consumed. The reasons is that microbial contamination is one of the main factors causing food spoilage (Aneja et al., 2014; Rawat, 2015; Wareing \& Davenport, 2005).

Another problem faced by traditional herbal medicine sellers is related to the decline in the nutritional quality of herbal medicine. The decrease in the nutritional quality of the food products is one of the problems that often occurs due to the production process that does not apply SOP. In the production of traditional herbal medicine, nutritional deficiencies can occur due to the production process that involves cooking at high temperatures for too long. High temperatures in cooking can damage various nutrients contained in food ingredients (Devi, 2015; Fillion \& Henry, 1998; Otemuyiwa et al., 2018; Tyagi et al., 2015).

In addition to the decrease on nutritional quality, the production of traditional herbal medicine so as problems occurred during packaging is prone to causing the product to become carcinogenic. Carcinogenic is a term that refers to cancer-causing agents (Klug et al., 2012; Snustad \& Simmons, 2012). One of the causes on the emergence of cancer is the consumption of plastic into human body (Ahmed, 2012; Halden, 2010; Verma et al., 2016). In this regard, herbal products that are still hot are usually stored into packaging process by the sellers by pouring it into plastic bottles. The heat of the herbal drink can melt the walls of the plastic bottle, so that some of the plastic particles will dissolve into the drink. The plastic particles can enter the body when herbal medicine is consumed by costumers.

The next problem is the low amount of herbal medicine production. Traditional herbal medicine sellers are often limited to produce only 10 to 20 bottles of herbal medicine per day. This limitation is caused by two factors. The first factor is due to limited production tools and materials. Production, packaging, and marketing problems are the main problems that must be addressed. The use of technology can help production process as an alternative to increase the quality and quantity of herbal medicine production. The use of packaging technology that is more practical and safer can also be used as a solution to the problem. In this community service program, the team then designed herbal medicine production tool according to the data that had been derived. Both machines were completed in the second week of November (Figure 2). 


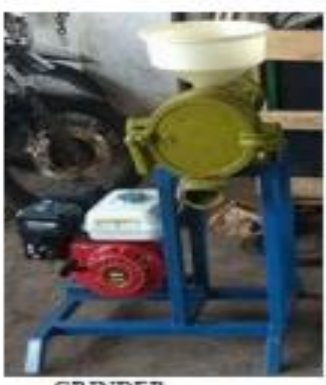

GRINDER

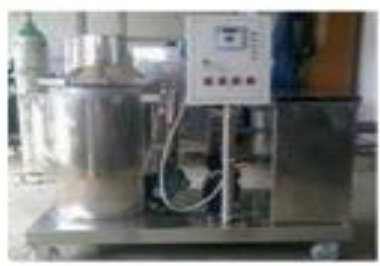

EVAPORATOR
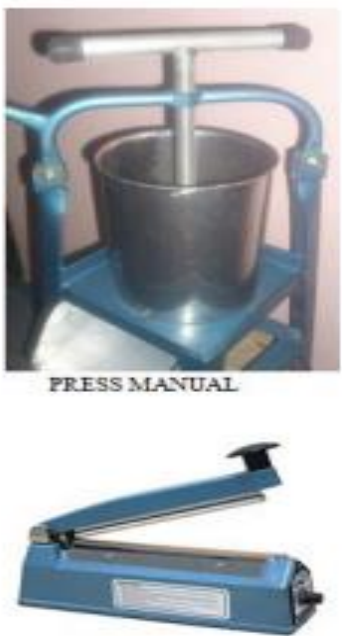

PACKAGING

Figure 2. Production machines designed and distributed to partners of herbal medicine sellers

After the two machines had been produced, the machines were distributed to partner groups. The distribution of the machine was carried out in two stages. First, the distribution of the dried herbal medicine production system given to the community group in Jetis, Malang. Second, the distribution of the wet herbal production system given to the community group in Dadaprejo Village, Areng-areng, Malang. The distribution of tools was also followed by the handing over of tools from the team to the two community groups.

After the two groups received the herbal medicine production system that had been developed, training activities and assistance on how to use and maintain the machines were organized by the team. The training schedule was adjusted to the schedule of trainers, lecturer team, and community group partners. The main trainer who trained the use and maintenance of the machines was Mr. Faris from Machine Workshop of Karya Brawijaya. In these training activities, apart from being trained by Mr. Faris, the lecturer team and students were also involved during the training process. The training activities on the first day focused on introducing tools, installing tools at the home of the head of the community group, and demonstrating the use of tools. Due to the time-consuming installation of the tool, the tool demonstration on the first day was only carried out on the grinder machine. Meanwhile, for the demonstration on the use of the tool was done in the second day. On the second day, demonstrations were carried out from grinding machine to packaging machines. In addition, the activities on the second day, the trainer still dominated on the use of tools. Next, the training on the third to sixth day focused on getting community groups to use the machines they had received. The results of the training on the sixth day show that members of the community groups were less rigid in using the machine when compared to the training on the third day. Some documentations of this training activity are shown in Figure 3.

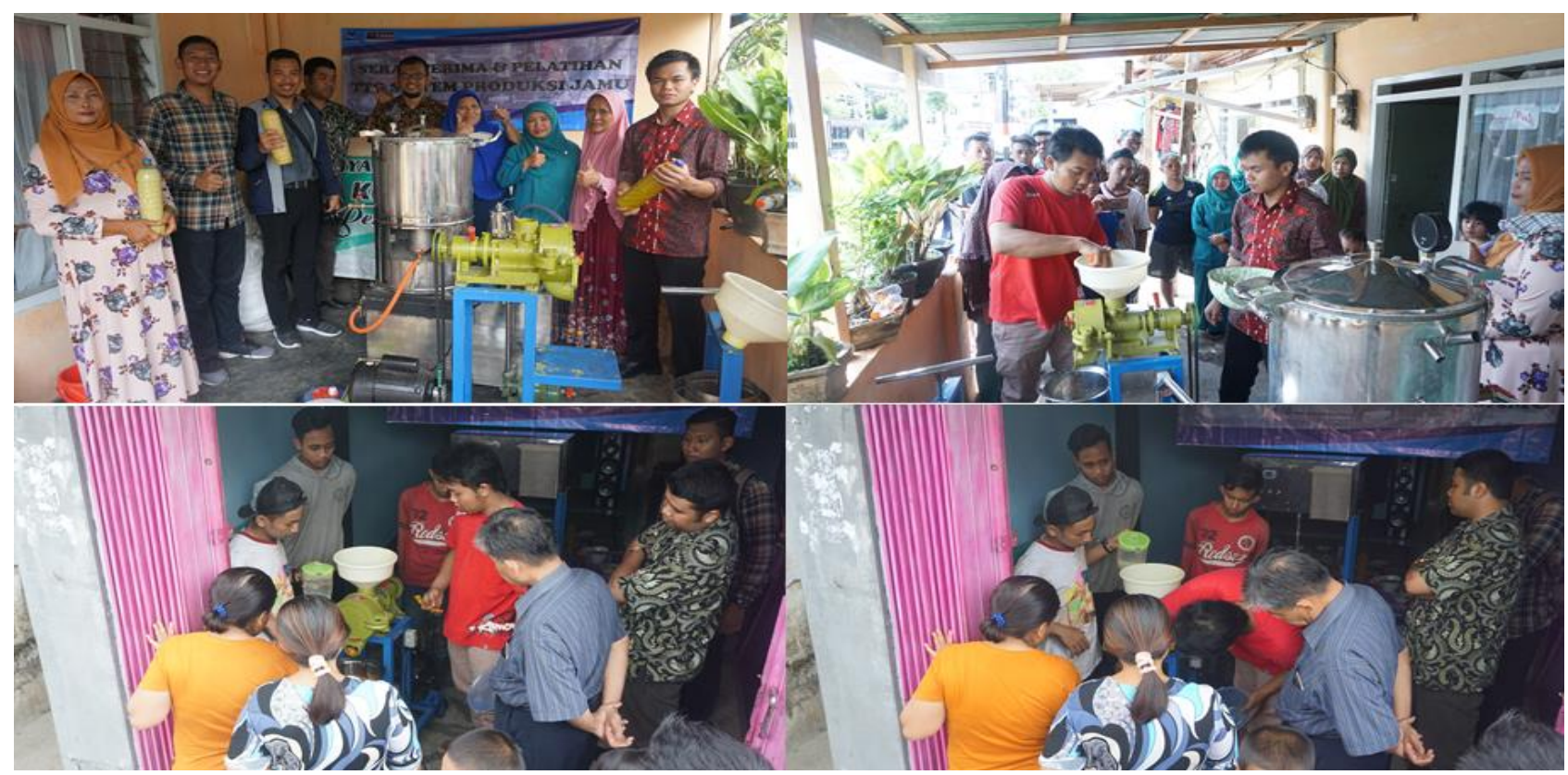

Figure 3. Production machines designed and distributed to partners of herbal medicine sellers 
The provision and training on the use of herbal medicine processing technology is an important step in improving the hygiene of herbal medicine production. The traditional herbal medicine processing with improvised kitchen utensils increases the risk of germ contamination to the herbs produced. The presence of germs in food or beverage products will harm consumers because they are harmful to humans (Hamad, 2012; Uçar et al., 2016). The presence of bacteria in these processed products can cause various diseases (Baroni et al., 2013; Hernández-Cortez et al., 2017). With the presence of herbal medicine machine unit, the chance of germ contamination will be minimized. Therefore, the implementation of this community service program can improve the quality of herbal medicine product, particularly in terms of health.

Although this community service program has been able to provide machine units for herbal medicine production, this activity still needs to be carried out on an ongoing basis. The existence of a production machine unit can indeed overcome the problem on the low amount of herbal medicine production. However, efforts to increase marketing scale also need to be undertaken. To achieve this goal, online-based marketing training needs to be carried out. This effort is in line with the development of human civilization which has come into the era of information and technology. In this era, the use of internet can be a medium in promoting economic products (Leeflang et al., 2014), including herbal medicine (Wadjdi et al., 2020). The use of internet in marketing is not only done through website or marketplace (Rangaswamy et al., 2020), but also can be done through social media (Alalwan et al., 2017; Si, 2015). Therefore, in the next program, training on the use of social media and other internet-based media needs to be conducted to optimize the marketing process.

\section{CONCLUSION}

This community service aims to solve hygiene problems and low production capability of traditional herbal medicine sellers around UMM area. The activities on this community service involves identifying partners' problems and alternative solutions, designing appropriate technology, as well as training on the use of the appropriate technology. The appropriate technology developed is a machine for herbal medicine production. There are two machine units, a machine to produce herbal drink (liquid) medicine and a machine to produce herbal powder medicine. After the machines have been produced, a training that involves all partners are undertaken. The partners have been enthusiastically participating in the trainings.

\section{ACKNOWLEDGEMENT}

Thanks to the Ministry of Research, Technology, and Higher Education (KEMENRiSTekDIKTI) 2018 for funding this community service activity through the Appropriate Technology Application Program (Program Penerapan Teknologi Tepat Guna/PPTTG). Also, acknowledgment is expressed to Directorate of Research and Community Service of Universitas Muhammadiyah Malang for facilitating this community service.

\section{REFERENCES}

Ahmed, H. G. (2012). Cancer awareness survey on exposure and attitude toward the commonn chemical carcinogenes in Northern State of Sudan. Management in Health, 9-12. http://journal.managementinhealth.com/index.php/rms/article/viewFile/247/774

Alalwan, A. A., Rana, N. P., Dwivedi, Y. K., \& Algharabat, R. (2017). Social media in marketing: A review and analysis of the existing literature. Telematics and Informatics, 34(7), 1177-1190. https://doi.org/10.1016/j.tele.2017.05.008

Aneja, K. R., Dhiman, R., Aggarwal, N. K., \& Aneja, A. (2014). Emerging preservation techniques for controlling spoilage and pathogenic microorganisms in fruit juices. International Journal of Microbiology, 2014. https://doi.org/10.1155/2014/758942

Baroni, S., Aparecida, I., Patera, R., de Moura, A. C., Silva Pinto, F. G. da, \& Sartori Cardoso da Roch, C. L. de M. (2013). Microbiological contamination of homemade food. In I. Muzzalupo (Ed.), Food Industry. InTech. https://doi.org/10.5772/53170

Basri, B., \& Assidiq, M. (2019). Peningkatan kualitas produksi melalui transformasi Kemasan produk pada usaha pembuatan jamu kunyit. CARADDE: Jurnal Pengabdian Kepada Masyarakat, 2(1), 139-143. https://doi.org/10.31960/caradde.v2i1.264

Devi, R. (2015). Food processing and impact on nutrition. Sch J Agric Vet Sci., 2(4A), 304-311. http://saspjournals.com/wp-content/uploads/2015/08/SJAVS-24A304-311.pdf

Elfahmi, Woerdenbag, H. J., \& Kayser, O. (2014). Jamu: Indonesian traditional herbal medicine towards rational phytopharmacological use. Journal of Herbal Medicine, 1-23. https://doi.org/10.1016/j.hermed.2014.01.002

Fhitryani, S., Suryanto, D., \& Karim, A. (2017). Pemeriksaan Escherichia coli, Staphylococcus aureus dan Salmonella sp. pada jamu gendong yang dijajakan di Kota Medan. BioLink, 3(2), 142-151. http://ojs.uma.ac.id/index.php/biolink/article/download/845/821

Fillion, L., \& Henry, C. J. K. (1998). Nutrient losses and gains during frying: A review. International Journal of Food Sciences and Nutrition, 49(2), 157-168. https://doi.org/10.3109/09637489809089395 
Gunawan, R., \& Mustofa, K. (2017). Finding knowledge from Indonesian traditional medicine using semantic web rule language. International Journal of Electrical and Computer Engineering (IJECE), 7(6), 3674-3682.

https://doi.org/10.11591/ijece.v7i6.pp3674-3682

Halden, R. U. (2010). Plastics and health risks. Annual Review of Public Health, 31(1), 179-194. https://doi.org/10.1146/annurev.publhealth.012809.103714

Hamad, S. H. (2012). Factors affecting the growth of microorganisms in food. In R. Bhat, A. K. Alias, \& G. Paliyath (Eds.), Progress in Food Preservation (pp. 405-427). John Wiley \& Sons. https://doi.org/10.1002/9781119962045.ch20

Hernández-Cortez, C., Palma-Martínez, I., Gonzalez-Avila, L. U., Guerrero-Mandujano, A., Solís, R. C., \& CastroEscarpulli, G. (2017). Food poisoning caused by bacteria (Food toxins). In N. Malangu (Ed.), Poisoning - From Specific Toxic Agents to Novel Rapid and Simplified Techniques for Analysis. InTech. https://doi.org/10.5772/intechopen.69953

Klug, W. S., Cummings, M. R., Spencer, C. A., \& Palladino, M. A. (2012). Concepts of Genetics (10th ed.). Benjamin Cummings.

Lailiyah, M., Mulyati, T. A., \& Pujiono, F. E. (2020). Pelatihan pembuatan jamu mix dan jahe wangi pada kelompok ibu rumah tangga di Desa Badal Pandean. Jurnal ABDINUS : Jurnal Pengabdian Nusantara, 3(2), 194-203. https://doi.org/10.29407/ja.v3i2.13730

Leeflang, P. S. H., Verhoef, P. C., Dahlström, P., \& Freundt, T. (2014). Challenges and solutions for marketing in a digital era. European Management Journal, 32(1), 1-12. https://doi.org/10.1016/j.emj.2013.12.001

Maulan, R., \& Fikriah, V. (2020). Edukasi pengemasan dan pemasaran bagi penjual jamu gendong di Lebak Bulus, Cilandak Jakarta Selatan. Seminar Nasional Pengabdian Masyarakat LPPM UMJ, 1-10.

Mills, J., Donnison, A., \& Brightwell, G. (2014). Factors affecting microbial spoilage and shelf-life of chilled vacuumpacked lamb transported to distant markets: A review. Meat Science, 98(1), 71-80. https://doi.org/10.1016/j.meatsci.2014.05.002

Natadjaja, L., Tripoli, F., \& Wahyono, B. (2014). The ideal female body on the packaging design of traditional medicine (jamu). Journal of Arts and Humanities (JAH), 3(4), 51-59.

Otemuyiwa, I. O., Falade, O. S., \& Adewusi, S. R. A. (2018). Effect of various cooking methods on the proximate composition and nutrient contents of different rice varieties grown in Nigeria. International Food Research Journal, 25(2), 747-754. http://www.ifrj.upm.edu.my/25 (02) 2018/(42).pdf

Primatika, R. A., Nugroho, W. S., \& Abadi, R. D. (2015). Analisis cemaran Staphylococcus aureus pada gelas, darah segar, dan jamu dengan ramuan darah ular kobra Jawa (Naja sputatrix). Jurnal Sain Veteriner, 33(2), 190-194. https://jurnal.ugm.ac.id/jsv/article/download/17918/14681

Rahardjanto, A., Nurwidodo, N., \& Mas'odi, M. (2019). Implementasi teknologi tepat guna untuk mengatasi permasalahan IRT ramuan Madura di Kabupaten Sumenep. International Journal of Community Service Learning, 3(4), 173-185. https://doi.org/10.23887/ijcsl.v3i4.21788

Rangaswamy, A., Moch, N., Felten, C., van Bruggen, G., Wieringa, J. E., \& Wirtz, J. (2020). The role of marketing in digital business platforms. Journal of Interactive Marketing, 51, 72-90. https://doi.org/10.1016/j.intmar.2020.04.006

Rawat, S. (2015). Food spoilage: Microorganisms and their prevention. Asian Journal of Plant Science and Research, 5(4), 47-56. http://www.imedpub.com/articles/food-spoilage-microorganisms-and-their-prevention.pdf

Si, S. (2015). Social media and its role in marketing. Business and Economics Journal, 7(1), 1-5. https://doi.org/10.4172/2151-6219.1000203

Snustad, D. P., \& Simmons, M. J. (2012). Genetics. Wiley.

Suci Asriani, P., Bonodikun, \& Yuliarti, E. (2015). Pemberdayaan perempuan pengrajin jamu gendong melalui penerapan teknologi diversivikasi produk olahan. Jurnal Bisnis Tani, 1(1), 1-4. https://doi.org/10.35308/jbt.v1i1.583

Sukmawati, P. A., Proborrini, M. W., \& Kawuri, R. (2012). Identifikasi fungi dan total bakteri pada jamu tradisional di pasar kedonganan Kelurahan Jimbaran Kabupaten Badung Provinsi Bali. Jurnal Biologi, 16(2), 31-35. http://thescipub.com/pdf/10.3844/ojbsci.2017.285.289

Torri, M. C. (2013). Knowledge and risk perceptions of traditional jamu medicine among urban consumers. European Journal of Medicinal Plants, 3(1), 25-39.

http://www.journalrepository.org/media/journals/EJMP_13/2012/Dec/1354796054Torri_312012EJMP1813.pdf

Tyagi, S. B., Kharkwal, M., \& Saxena, T. (2015). Impact Of Cooking On Nutritional Content Of Food. DU Journal of Undergraduate Research and Innovation, 1(3), 180-186. http://journals.du.ac.in/ugresearch/pdf-vol3/U18.pdf

Uçar, A., Yilmaz, M. V., \& Çakiroglu, F. P. (2016). Food safety - Problems and solutions. In H. A. Makun (Ed.), Significance, Prevention and Control of Food Related Diseases. InTech. https://doi.org/10.5772/63176

Valero, A., Carrasco, E., \& Ma, R. (2012). Principles and methodologies for the determination of shelf-life in foods. In Trends in Vital Food and Control Engineering (pp. 3-42). InTech. https://doi.org/10.5772/35353

Verma, R., Vinoda, K. S., Papireddy, M., \& Gowda, A. N. S. (2016). Toxic pollutants from plastic waste- A review. 
Procedia Environmental Sciences, 35, 701-708. https://doi.org/10.1016/j.proenv.2016.07.069

Wadjdi, M. F., Cahyaning Thias, T. A., Qatrunnada, L., Asga, I. D., Ni’mah, M., Makruf, A., R. Hadiyansa, F., Febriansyah, A. W., Efendi, A., Alfadlilatul Azza, M. W., \& Choiruddin, A. (2020). Pengembangan jamu olahan rumah tangga untuk meningkatkan perekonomian masyarakat melalui pemasaran e-commerce. Jurnal Pembelajaran Pemberdayaan Masyarakat (JP2M), 1(2), 143. https://doi.org/10.33474/jp2m.v1i2.6506

Wareing, P., \& Davenport, R. R. (2005). Microbiology of soft drinks and fruit juices. Chemistry and Technology of Soft Drinks and Fruit Juices, November 2007, 279-297. https://doi.org/10.1002/9780470995822.ch11

Widyowati, R., Kusumawati, I., Ekasari, W., \& Purwitasari, N. (2018). Pengembangan produksi jamu dan bahan spa bagi penjual jamu gendong dan simplisia di Bantul, Yogyakarta. Jurnal Pengabdian Kepada Masyarakat, 2(4), 346349.

Wijaya, I. (2012). Socio-cultural knowledge and perceptions of jamu consumption risk: Local wisdom of urban Javanese community and its relation to the integration of traditional jamu medicine into formal health system in Indonesia. JKM, 11(2), 129-139.

Wijaya, S. H., Tanaka, Y., Hirai, A., Afendi, F. M., Batubara, I., Ono, N., Darusman, L. K., \& Kanaya, S. (2016). Utilization of KNApSAcK family databases for developing herbal medicine systems. Journal of Computer Aided Chemistry, 17, 1-7. https://www.jstage.jst.go.jp/article/jcac/17/0/17_1/_pdf

Yulagustinus, \& Tridjaja, N. O. (2017). Jamu-A healthy drink of Indonesia. Journal of Food Science and Engineering, 7, 221-226. https://doi.org/10.17265/2159-5828/2017.04.007

Zuhrie, M. S., Purbodjati, P., \& Drastiawati, N. S. (2018). Peningkatan produktivitas UKM jamu tradisional melalui penerapan mesin pengupas rempah-rempah. Jurnal Pengabdian Kepada Masyarakat, 2(4), 285-288. 